\title{
SZCZEPIENIA PRZECIWKO GRYPIE U PERSONELU MEDYCZNEGO
}

\author{
INFLUENZA VACCINATIONS OF HEALTH CARE PERSONNEL
}

\author{
${ }^{1}$ Warszawski Uniwersytet Medyczny / Medical University of Warsaw, Warszawa, Poland \\ Katedra i Zakład Medycyny Rodzinnej z Oddziałem Klinicznym Chorób Wewnętrznych i Metabolicznych / Department of Family \\ Medicine, Clinical Ward of Internal and Metabolic Diseases \\ ${ }^{2}$ Narodowy Instytut Zdrowia Publicznego - Państwowy Zakład Higieny / National Institute of Public Health - National Institute \\ of Hygiene, Warszawa, Poland \\ Zakład Badania Wirusów Grypy, Krajowy Ośrodek ds. Grypy / Department of Influenza Research, National Influenza Center \\ ${ }^{3}$ Uniwersytet Szczeciński / University of Szczecin, Szczecin, Poland \\ Zakład Immunologii, Wydział Biologii / Department of Immunology, Faculty of Biology
}

\section{STRESZCZENIE}

Grypa jest jedną z częstszych infekcji dróg oddechowych, zachorowania na nią występują we wszystkich grupach wiekowych pacjentów na całym świecie. Liczba zachorowań na grypę sezonową i zgonów z powodu jej powikłań jest znaczna w skali globalnej. Szczepienia, również przeciwko grypie, są istotnym osiągnięciem medycyny ostatniego stulecia, jednak problemem pozostaje zwalczanie grypy za pomocą szczepień ochronnych wśród personelu medycznego. Szczepienie personelu medycznego jest procedurą o udowodnionym bezpieczeństwie i skuteczności, zapewnia zapobieganie zachorowaniom wśród pacjentów. Mimo licznych rekomendacji eksperckich stan zaszczepienia pracowników medycznych pozostaje niski. W celu zwiększenia liczby zaszczepionych pracowników medycznych konieczne jest prowadzenie kampanii edukacyjnych, które mają na celu polepszenie stanu wiedzy personelu na temat grypy, jej powikłań, szczepień przeciwko grypie, ze szczególnym uwzględnieniem ich bezpieczeństwa i skuteczności. Szczepieni pracownicy najczęściej decyzję o wykonaniu szczepienia motywują chęcią ochrony siebie oraz chęcią ochrony przed zakażeniem swoich pacjentów i ich rodzin. Z kolei wśród przyczyn nieszczepienia wymieniane są: brak czasu, błędne przekonania o nieskuteczności szczepienia, brak potrzeby szczepienia z powodu bagatelizowania choroby i jej powikłań, obawa przez niepożądanymi odczynami poszczepiennymi. Konieczne jest wdrożenie strategii mających na celu edukację personelu medycznego w zakresie stosowania szczepień przeciwko grypie w celu zwiększenia wyszczepialności przeciwko grypie w populacji pracowników medycznych. Med. Pr. 2013;64(1):119-129

Słowa kluczowe: grypa, szczepienia ochronne, personel medyczny

\begin{abstract}
Influenza is one of the most common respiratory diseases affecting people of all age groups all over the world. Seasonal influenza leads to substantial morbidity and mortality on a global scale. Vaccines are undeniably one of the most important health advances of the past century, however, managing influenza in working populations remains a difficult issue. Vaccination of health care workers (HCW) is an efficient way to reduce the risk of occupational infection and to prevent nosocomial transmission to vulnerable patients. Despite this, achieving high immunization rates among those professionals is a challenge. Knowledge and attitudes of healthcare providers have significant impact on the frequency with which vaccines are offered and accepted, but many HCWs are poorly equipped to make informed recommendations about vaccine merits and risks. Principal reasons for vaccination are the willing not to be infected and avoiding transmission to patients and the family. The main reasons for refusing is lack of time, a feeling of invulnerability to vaccination, conviction of not being at risk, of being too young or in good health. Misconceptions about influenza vaccine efficacy, like adverse effects, and fear of contracting illness from the vaccine are significantly associated with noncompliance with vaccination. Therefore, strategies to increase awareness of the importance of recommending influenza immunization among health professionals are required. Med Pr 2013;64(1):119-129
\end{abstract}

Key words: influenza, vaccination, health care workers

Adres 1. autorki: Katedra i Zakład Medycyny Rodzinnej z Oddziałem Klinicznym Chorób Wewnętrznych i Metabolicznych, Warszawski Uniwersytet Medyczny, ul. Banacha 1a, blok F, 02-092 Warszawa, e-mail: anitsch@amwaw.edu.pl Nadesłano: 12 listopada 2012, zatwierdzono: 5 grudnia 2012 


\section{EPIDEMIOLOGIA GRYPY W POLSCE I NA ŚWIECIE}

W 1996 roku Światowa Organizacja Zdrowia (World Health Organization - WHO) w swoim raporcie umieściła grypę wśród chorób o rosnącym znaczeniu (ponownie pojawiających się - re-emerging diseases). Obecnie żadne gremium eksperckie nie uznaje za możliwe wyeradykowanie choroby, co przede wszystkim wynika $\mathrm{z}$ dużej zmienności antygenowej wirusów grypy, przejawiającej się w postaci przesunięcia antygenowego lub skoku antygenowego (1).

Pierwsze opisy grypy pochodzą od ojca medycyny - Hipokratesa z 412 roku przed naszą erą, a historia ludzkości obfituje $\mathrm{w}$ opisy epidemii i pandemii tej choroby, przy czym najbardziej wiarygodne są dane z ostatnich 250 lat. W 2009 roku zanotowano pierwszą w XXI w. pandemię grypy wywołaną przez wirus typu A (H1N1)pdm09 (1).

Według szacunków WHO na grypę i zakażenia wywołane przez wirusy grypopodobne corocznie choruje od 330 mln do 1,575 mld ludzi (1,2). Liczbę zachorowań i podejrzeń zachorowań na grypę w Polsce przedstawia tabela 1 .

\section{PRZEBIEG I POWIKŁANIA GRYPY}

Grypa jest ostrą chorobą zakaźną wywoływaną przez wirusy z rodziny Orthomyxoviridae. Źródłem zakażenia jest chory człowiek (lub zwierzę - w przypadku zakażeń wywołanych wirusem grypy typu A (H5N1)/HPAI, tzw. grypy ptaków). Zakażenie przenosi się drogą kropelkową, kontaktową i aerozolową. Okres inkubacji choroby trwa zwykle 1-4 dni (średnio: 1-2 dni). Okres zakaźności choroby jest różny w zależności od wieku pacjenta i stanu odporności. Dzieci wydalają wirusa od 6 do 10 dni od pojawienia się objawów chorobowych, dorośli - zwykle jeden dzień przed pojawieniem się objawów i 5-7 dni po ich pojawieniu się, a u osób $\mathrm{w}$ immunosupresji wydalanie wirusów grypy może trwać kilka tygodni lub nawet miesięcy $(1,2)$.

Objawy kliniczne grypy sezonowej obejmują: nagły początek choroby, kaszel, katar, ból gardła, gorączkę, dreszcze, bóle stawowo-mięśniowe, bóle głowy, bóle w klatce piersiowej, złe samopoczucie, nudności i wymioty. Objawy kliniczne ustępują w ciągu 3-5 dni, ale kaszel i złe samopoczucie mogą trwać dłużej, nawet ponad 2 tygodnie $(1,2)$. Częstość występowania poszczególnych objawów grypy przedstawia tabela $2(1,2)$.

Tabela 1. Zapadalność na grypę w Polsce w sezonach epidemicznych 1997-2012 (1,2) Table 1. Incidence of influenza in Poland in epidemiological seasons 1997-2012 (1,2)

\begin{tabular}{|c|c|c|}
\hline $\begin{array}{l}\text { Sezon epidemiczny } \\
\text { Epidemiological season }\end{array}$ & $\begin{array}{c}\text { Zachorowania na grypę } \\
\text { Influenza cases } \\
{[\mathrm{n}]}\end{array}$ & $\begin{array}{l}\text { Współczynnik zapadalności na } 100000 \text { populacji } \\
\text { Incidence per } 100.000 \text { population }\end{array}$ \\
\hline $1998 / 1999$ & 2396762 & 6200,90 \\
\hline $1999 / 2000$ & 1530510 & 3959,93 \\
\hline $2001 / 2002$ & 210284 & 544,18 \\
\hline $2002 / 2003$ & 1220306 & 3157,64 \\
\hline $2003 / 2004$ & 341418 & 3157,64 \\
\hline $2004 / 2005$ & 702772 & 1842,23 \\
\hline $2007 / 2008$ & 235991 & 618,47 \\
\hline $2008 / 2009$ & 558719 & 1465,80 \\
\hline $2009 / 2010$ & 836861 & 2193,40 \\
\hline $2010 / 2011$ & 1034061 & 2709,30 \\
\hline $2011 / 2012$ & 1086911 & 2838,99 \\
\hline
\end{tabular}


Tabela 2. Częstość występowania objawów poszczególnych objawów klinicznych u pacjentów z potwierdzoną laboratoryjnie grypą (1,2) Table 2. Frequency of clinical symptoms among patients with laboratory confirmed influenza $(1,2)$

\begin{tabular}{|c|c|c|c|}
\hline $\begin{array}{l}\text { Objaw chorobowy } \\
\text { Clinical symptom }\end{array}$ & \multicolumn{3}{|c|}{$\begin{array}{c}\text { Częstość występowania } \\
\text { Frequency } \\
{[\%]} \\
\end{array}$} \\
\hline Kaszel / Caugh & 75 & $80-90$ & $60-100$ \\
\hline Bóle stawowo-mięśniowe / Musculo-sceletal pain & $60-80$ & $60-80$ & 50 \\
\hline Ból głowy / Headache & 90 & 75 & $80-100$ \\
\hline Nieżyt nosa / Sneezing & 25 & 80 & 90 \\
\hline
\end{tabular}

Grypa niepowikłana ma charakter samoograniczający się, a przyczyną zgonu mogą być powikłania pogrypowe wymienione $\mathrm{w}$ tabeli 3 . Częstość występowania powikłań pogrypowych szacuje się na $6 \%$, a w grupach ryzyka powikłania występują częściej $(1,2)$.

Tabela 3. Powikłania grypy u dzieci i dorosłych $(1,2)$

Table 3. Complications of influenza among children and adults $(1,2)$

\begin{tabular}{lc}
\hline Kategoria & Powikłania \\
Category & Complications \\
\hline
\end{tabular}

Powikłania pulmonologiczne /

/ Pulmonological complications

Powikłania kardiologiczne / Cardiological complications

Powikłania neurologiczne / Neurological complications

Powikłania ginekologiczno-położnicze / / Gynecological and obstetric complications

Zaostrzenie lub pogorszenie chorób przewlekłych / Deterioration of chronic diseases

Inne / Others pierwotne zapalenie płuc, wtórne zapalenie płuc, zapalenie oskrzeli, zapalenie zatok obocznych nosa, zapalenie oskrzelików, ostry zespół niewydolności oddechowej / primary pneumonia, secondary pneumonia, bronchitis, sinusitis, bronchiolitis, acute respiratory distress syndrome

zapalenie mięśnia sercowego, zapalenie wsierdzia, zapalenie osierdzia, częstsze występowanie incydentów sercowo-naczyniowych oraz udaru mózgu po infekcji grypowej / myocarditis, endocarditis, pericarditis, more frequent cardio-vascular events and stroke after influenza infection

poprzeczne zapalenie rdzenia kręgowego, zapalenie opon mózgowo-rdzeniowych i mózgu, zapalenie móżdżku, encefalopatia, zespół Guillaina-Barrego / transverse myelitis, meningitis, meningoencephalitis, cerebellitis, encephalopathy, Guillain Barre syndrome

wzrost ryzyka poronienia i porodu przedwczesnego, częstsze występowanie schizofrenii u dzieci w przypadku zakażenia wewnątrzmacicznego / increased risk of spontaneous abortion and premature birth, increased risk of schizophrenia in case of intrauterine influenza infection

zaostrzenie astmy oskrzelowej, zaostrzenie przewlekłej obturacyjnej choroby płuc (POChP), zaostrzenie niewydolności krążenia, zaostrzenie objawów chorób przebiegających z otępieniem, zaostrzenie objawów choroby Parkinsona, pogorszenie kontroli glikemii u pacjentów z cukrzycą / deterioration of bronchial asthma, chronic pulmonary obstructive disease, dementia disorders, Parkinsons' disease, worse glicemia control in patients with diabetes

drgawki gorączkowe, zapalenie ucha środkowego, zespół Reya, wtórne zakażenia meningokokowe, wtórne zakażenia pneumokokowe, wtórne zakażenia gronkowcowe, wtórne zakażenia grzybicze, inne wtórne zakażenia bakteryjne, również wywołane przez patogeny atypowe, zespół wstrząsu toksycznego, zapalenie mięśni, mioglobinuria, rabdomioliza, niewydolność nerek, zapalenie rogówki, odrzut przeszczepu / / febrile seizures, otitis media, Rey syndrome, secondary meningococcal, pneumococcal, staphylococcal and fungal infections, infections caused by atypical pathogens, toxic syndrome, myositis, mioglobinuria, rhabdomyositis, renal insufficiency, corneitis, transplant rejection 


\section{SZCZEPIENIA PRZECIWKO GRYPIE}

W zapobieganiu grypie istotną rolę odgrywają procedury izolacji i właściwe postępowanie higieniczne, możliwa jest także profilaktyka farmakologiczna. Głównym orężem $\mathrm{w}$ walce $\mathrm{z}$ grypą są jednak szczepienia ochronne.

W Polsce od 1994 r. szczepienia przeciwko grypie zaliczane są do szczepień zalecanych. Zgodnie z Załącznikiem do Komunikatu Głównego Inspektora Sanitarnego z dnia 26 października 2011 r. (poz. 71) „Program Szczepień Ochronnych na rok 2012" są one zalecane osobom po 50. roku życia, osobom z grup ryzyka ciężkiego i powikłanego przebiegu grypy, a także zdrowym dzieciom w wieku od 6 miesięcy do 18 lat $(1,2)$.

Zgodnie z zaleceniami Amerykańskiego Komitetu Doradczego ds. Szczepień Ochronnych (American Committe on Immunization Practices - ACIP) szcze- pienia przeciwko grypie powinny być zalecane i corocznie wykonywane ze wskazań klinicznych i epidemiologicznych (tab. 4).

\section{GRYPA PROBLEMEM ZDROWOTNYM PERSONELU MEDYCZNEGO}

$\mathrm{Na}$ postawie wyników badań serologicznych szacuje się, że corocznie kontakt $\mathrm{z}$ wirusami grypy ma nawet $25 \%$ pracowników medycznych (4). Interesujące jest też, że 25\% osób, które miały bezpośredni kontakt z pacjentami $\mathrm{z}$ wynikami badań serologicznych wskazujących na przebyte zakażenie wirusami grypy, nie podawało w wywiadzie występowania objawów chorobowych. Może to wskazywać na możliwy łagodny lub skąpoobjawowy przebieg zakażenia, przy czym osoby takie nadal mogą być źródłem zakażenia zarówno dla pacjentów, jak i dla innych osób z personelu medycznego (5).

Tabela 4. Zalecenia Amerykańskiego Komitetu Doradczego ds. Szczepień (ACIP) dotyczące posezonowych szczepień przeciwko grypie $(1,3)$

Table 4. American Committee on Immunization Practices (ACIP) recommendations for seasonal influenza vaccinations $(1,3)$

Wskazania kliniczne do szczepień przeciwko grypie Clinical recommendations for influenza vaccination
Wskazania epidemiologiczne do szczepień przeciwko grypie Epidemiological recommendations for influenza vaccination
Zdrowe dzieci w wieku od 6. miesiąca życia do 18. roku życia / Healthy children aged 6 months 18 years

Dzieci i dorośli z przewlekłymi chorobami układu oddechowego, takimi jak: astma oskrzelowa, mukowiscydoza, przewlekła obturacyjna choroba płuc / Children and adults with chronic pulmonary disorders like: bronchial asthma, mucowiscidosis, chronic obturative disease

Dzieci i dorośli, którzy w roku poprzedzającym szczepienie wymagali regularnych badań lekarskich lub hospitalizacji z powodu przewlekłych chorób metabolicznych (w tym cukrzycy), dysfunkcji nerek, hemoglobinopatii, immunosupresji (w tym spowodowanej przyjmowaniem leków immunosupresyjnych i zakażeniem HIV) / / Children and adults who during previous season required regular visits or hospitalizations due to chronic metabolic diseases (including diabetes), renal disfunction, hemoglobinopathy, immunosupression (including the use of immunosupresive medicines and HIV carriers)

Dzieci (od 6. miesiąca życia do 18. roku życia) i dorośli, którzy podlegają długoterminowej terapii aspirynowej i z tego powodu mogą być narażeni na wystąpienie zespołu Reya w przypadku zakażenia wirusem grypy / Children (aged 6 months - 18 years) and adolescents who are receiving long-term aspirin therapy and who might be at risk for experiencing Reye syndrome after influenza virus infection

Kobiety w ciąży i planujące ciążę w nadchodzącym sezonie epidemicznym /

/ Women who are or will be pregnant during the influenza season

Osoby w wieku powyżej 50 lat / Persons older than 50 years
Lekarze, pielęgniarki oraz inny personel medyczny zarówno w lecznictwie ambulatoryjnym, jak i szpitalnym / Heath care workers, employed both in ambulatory care settings and hospitals

Pracownicy domów opieki i innych placówek dla przewlekle chorych, którzy mają kontakt z chorymi lub pensjonariusza / / Workers employed at nursing homes and other long-termcare facilities

Opiekunowie osób z grup ryzyka przebywających w domu / / Household contacts and caregivers of persons with medical conditions that put them at higher risk for severe complications from influenza

Osoby mające kontakt $\mathrm{z}$ dziećmi w wieku poniżej 5 lat (ze szczególnym uwzględnieniem dzieci w wieku poniżej 6 miesięcy) oraz z osobami w wieku powyżej 50 lat / / Household contacts and caregivers of children aged less than 5 years and adults aged more than 50 years, with particular emphasis on vaccinating of children aged $<6$ months

Pracownicy służb publicznych, np. policjanci, wojskowi, nauczyciele, pracownicy handlu, transportu, budownictwa / / Policemen, soldiers, teachers and workers employed in the commerce, transport and construction sectors 
Epidemie chorób zakaźnych, w tym ogniska zachorowań na grypę, w placówkach opieki zdrowotnej mogą mieć wymierne i poważne konsekwencje $(6,7)$ :

finansowe - np. koszt opanowania ogniska epidemicznego (izolacja pacjentów, wdrożenie leczenia przeciwwirusowego), koszt czasowego zawieszenia świadczenia usług medycznych z powodu wstrzymania przyjęć, koszt zatrudnienia personelu przeznaczonego jedynie do opieki nad wybranymi, chorymi na grypę pacjentami;

wizerunkowe - utrata zaufania pacjentów, utrudnienia odwiedzin;

\section{prawne - pozwy o odszkodowania.}

Personel medyczny jest narażony na zakażenie drogą kropelkową lub kontaktową wirusami grypy w miejscu pracy i może się stać źródłem zakażenia dla pacjentów. Ich znaczna część należy do grupy wysokiego, ciężkiego przebiegu i powikłań grypy ze względu na wiek i choroby przewlekłe np. układu oddechowego (astma oskrzelowa czy przewlekła obturacyjna choroba płuc), układu sercowo-naczyniowego czy choroby metaboliczne (np. cukrzycę). Wykazano, że nawet 75\% lekarzy przyznaje, że wykonuje obowiązki zawodowe, mając objawy chorobowe świadczące o aktualnej infekcji dróg oddechowych (4).

Powikłania grypy, hospitalizacje oraz zgony z powodu grypy i jej skutków występują głównie wśród chorych przewlekle, niemowląt i najmłodszych dzieci (do 2-5. roku życia), seniorów i kobiet ciężarnych $(1,6,7)$. Szczepie- nie personelu medycznego jest szczególnie korzystne dla tych pacjentów, u których nie można wykonać szczepienia. Dotyczy to pacjentów np. zbyt młodych (niemowląt poniżej 6. miesiąca życia, dla których szczepionka nie jest zarejestrowana, a zaznaczyć należy, że opisano zachorowania na grypę nawet wśród noworodków), z przeciwwskazaniami medycznymi do szczepienia (np. wystąpienie ciężkiej reakcji anafilaktycznej po szczepieniu przeciwko grypie, znana alergia na którykolwiek składnik szczepionki), pacjentów, którzy w sposób niewystarczający odpowiadają na szczepienie (np. osoby w wieku 85 lat i powyżej, w immunosupresji), a także osób, których z powodu przeciwwskazań medycznych nie można leczyć lekami przeciwwirusowymi (głównie inhibitorami neuraminidazy). Szczepienie personelu medycznego przeciwko grypie jest więc elementem realizacji strategii kokonowej szczepień ochronnych (1).

Do szczepień personelu medycznego można wybrać każdą z zarejestrowanych i dostępnych w Polsce szczepionek przeciwko grypie i stosować zgodnie z zaleceniami producenta. Szczepionki przeciwko grypie zarejestrowane w Polsce przedstawia tabela 5. Szczepionkę należy podawać domięśniowo lub podskórnie (w przypadku współistniejących zaburzeń krzepnięcia); dostępna jest też szczepionka do podawania śródskórnego. Szczepionki są dostępne w aptekach i hurtowniach zwykle od września, zaleca się wykonanie szczepienia przed zbliżającym się sezonem epidemicznym typowym dla grypy, który w Polsce zwykle występuje od stycznia do

Tabela 5. Szczepionki przeciwko grypie zarejestrowane w Polsce $(1,2)$

Table 5. Vaccinations against influenza in Poland $(1,2)$

Sposób produkcji szczepionki

Type of vaccine production

Szczepionki produkowane na zarodkach kurzych / Influenza vaccine received in cultured chick embryos
Rodzaj szczepionki

Type of vaccine
Nazwa i producent szczepionki

Name and producer of vaccine szczepionki inaktywowane z rozszczepionym
winionem / inactivated influenza vaccines with
split virion

szczepionki inaktywowane podjednostkowe /

/ inactivated subunit vaccines

szczepionki wirosomalne / virosomal vaccines

szczepionka inaktywowana podjednostkowa /

/ inactivated subunit influenza vaccine

szczepionka inaktywowana $\mathrm{z}$ rozszczepionym winionem / inactivated influenza vaccine with split virion
Vaxigrip (Sanofi Pasteur SA, Francja / France); Fluarix

(GlaxoSmithKline, Wielka Brytania / UK; Begrivac

(Novartis Vaccines and Diagnostics, Szwajcaria /

/ Switzerland); ID Flu (Sanofi Pasteur SA, Francja / France)

Influvac (Abbott, Stany Zjednoczone / USA);

Agrippal (Novartis Vaccines and Diagnostics,

Szwajcaria / Switzerland)

Inflexal V (Berna Biotech I, Holandia / The Netherlands)

Optaflu (Novartis Vaccines and Diagnostics, Szwajcaria / Switzerland)

Preflucel (Baxter, Stany Zjednoczone / USA)
Szczepionki produkowane na hodowli tkankowej Vero / Influenza vaccine received in the Vero cell culture ermal vaccine.

* Szczepionka do podawania śródskórnego / Intradermal vaccine.
MDCK - linia hodowlana na psiej nerce / Madin-Darby Canine Kidney. 
marca $(1,2)$. Możliwe jest jednak i wskazane wykonane szczepienia nawet wtedy, gdy dane epidemiologiczne i z nadzoru wirusologicznego wskazują na aktualną obecność wirusów grypy w populacji.

Przeciwwskazania do szczepienia przeciwko grypie są nieliczne:

wiek poniżej 6. miesiąca życia,

ostra choroba przebiegająca z gorączką,

zaostrzenie choroby przewlekłej,

poważna reakcja anafilaktyczna po poprzedniej dawce szczepionki, uczulenie na którykolwiek składnik szczepionki,

zespół Guillaina-Barrégo w wywiadzie.

\section{KORZYŚCI ZE SZCZEPIEŃ PRZECIWKO GRYPIE DLA PERSONELU I DLA PACJENTÓW}

Wyniki opublikowanych badań wskazują na fakt, że szczepienie personelu placówek opieki zdrowotnej przeciwko grypie zapewniało istotne zmniejszenie umieralności ogólnej oraz zapadalności na choroby grypopodobne wśród pacjentów wymagających długoterminowej opieki $(6,7,8-10)$. Carman i wsp. wykazali, że uzyskując stan zaszczepienia personelu w domu opieki dla osób starszych na poziomie $50 \%$, zapewnia się redukcję śmiertelności wśród pensjonariuszy o 40\% (8).

Indywidualne korzyści dla personelu płynące ze szczepienia przeciwko grypie są mniej udokumentowane $(6,7)$. Odnotowano m.in. zmniejszenie liczby dni nieobecności $\mathrm{w}$ pracy $\mathrm{z}$ powodu zakażeń układu oddechowego, stwierdzono także zmniejszenie ryzyka zakażenia wirusem grypy (średnio o $88-89 \%)(11,12)$. $\mathrm{W}$ populacji szczepionych osób zdrowych $\mathrm{w}$ wieku produkcyjnym wykazano, że uzyskiwano niewielkie zmniejszenie liczby dni absencji chorobowej $\mathrm{w}$ pracy (o około 0,5 dnia) (11). Salgado i wsp. wykazali w grupie pracowników medycznych szczepionych przeciwko grypie zmniejszenie liczby potwierdzonych laboratoryjnie zachorowań na grypę z $42 \%$ do $9 \%$, a także zmniejszenie odsetka zakażeń szpitalnych w postaci infekcji dróg oddechowych z 32\% do 3\% (13).

\section{GRYPA JAKO ZAKAŻENIE SZPITALNE}

W literaturze znaleźć można opisy epidemii grypy w oddziałach szpitalnych, szerzące się wśród pacjentów wymagających szczególnej troski. W 1998 r. opisano epidemię na oddziale intensywnej opieki nad noworodkiem - zachorowało wtedy 19 spośród 54 pacjentów, zmarło 1 dziecko. Zaszczepione było tylko 15\% perso- nelu, a 29 osób przyznało, że zajmowało sie pacjentami w czasie trwania objawów infekcji dróg oddechowych (14). W tym samym roku na oddziale przeszczepu szpiku kostnego zachorowało 10 pacjentów, 1 osoba zmarła. Zaszczepione było $12 \%$ personelu, a 5 osób przyznało, że świadczyło obowiązek pracy z objawami chorobowymi) (15). Ogniska zakażeń wywołanych wirusami grypy opisano także na oddziałach przeszczepu nerek, hematologicznym, noworodkowym i pediatrycznym (w dwóch ostatnich wymienionych oddziałach dodatkowo zidentyfikowano jako czynniki ryzyka zakażenia wirusami grypy stosowanie sztucznej wentylacji oraz ciążę mnogą) (14,16-19).

Szczególną grupą pacjentów narażonych na wewnątrzszpitalne epidemie grypy są pensjonariusze placówek świadczących usługi opiekuńczo-lecznicze dla pacjentów przewlekle chorych. Opisano, że w sezonie epidemicznym, w czasie wystąpienia ogniska zachorowań na grypę w placówce, której pensjonariuszami były osoby w wieku powyżej 65 lat, odsetek zakażonych był bardzo wysoki i sięgał nawet 60\% (20). Ponieważ szczepienia przeciwko grypie osób w wieku podeszłym nie są tak efektywne jak u osób młodszych (30-40\% vs 70-90\%) i opisywano epidemie grypy w populacjach pensjonariuszy domów opieki, gdzie wyszczepialność była bardzo wysoka i sięgała nawet $90 \%$, konieczne jest w celu ochrony pacjentów wykonywanie szczepień personelu medycznego $(21,22)$.

W przypadku kontaktu $\mathrm{z}$ wirusami grypy w pracy nieszczepionego personelu medycznego wskazane jest jak najszybsze wykonanie szczepienia przeciwko grypie i ewentualne stosowanie przez 14 dni leków przeciwgrypowych (oseltamiwiru lub zanamiwiru) (23). Leki przeciwgrypowe (inhibitory neuraminidazy) stanowią cenne uzupełnienie szczepień przeciwko grypie, ale ich nie zastępują (23).

Należy pamiętać, że wśród personelu medycznego znajdują się także osoby w wieku powyżej 65 roku życia, z chorobami przewlekłymi takimi, jak przewlekła obturacyjna choroba płuc, astma oskrzelowa, oraz kobiety ciężarne. Osoby te powinny być szczepione przeciwko grypie ze wskazań klinicznych, a nie tylko epidemiologicznych (23).

\section{Jak zwiększyć stan zaszczepienia} personelu medycznego przeciwko grypie?

Mimo apeli wielu organizacji eksperckich stan zaszczepienia personelu medycznego przeciwko grypie pozostaje niski. W Stanach Zjednoczonych wynosi on 20 $-80 \%$ (średnio: $40-50 \%$ ), co zależy m.in. od specjaliza- 
cji oraz miejsca i stażu pracy (6). Do najczęściej szczepiących się należą lekarze pediatrzy, a najrzadziej szczepienia przeciwko grypie wykonują chirurdzy. Dane Centrum Zwalczania i Zapobiegania Chorób (Centers for Disease Control and Prevention - CDC) wskazują, że najczęściej szczepi się personel medyczny pracujący w szpitalach oraz osoby po 60. roku życia (6).

Wyniki wielu badań wskazują, że najczęściej wśród personelu medycznego szczepieniom przeciwko grypie poddają się lekarze, rzadziej pielęgniarki i inny personel medyczny. Wśród personelu domów opieki we Francji szczepiło się przeciwko grypie $48 \%$ lekarzy i $30 \%$ pielęgniarek (24). Znaczącą różnicę zauważyli także Fernandez i wsp. wśród personelu wybranego szpitalnego oddziału ratunkowego w Bostonie - szczepienie przeciwko grypie wykonało 94\% rezydentów, 82\% lekarzy i tylko $42 \%$ pielęgniarek (25).

W Polsce stan zaszczepienia jest skrajnie niski i zbliżony do tego obserwowanego $\mathrm{w}$ populacji generalnej, czyli wynosi $6 \%$ (1). Niski odsetek zaszczepionego personelu najczęściej wynika z (26-29):

lęku przed wystąpieniem niepożądanego odczynu poszczepiennego (NOP),

braku czasu na wykonanie szczepienia,

niewystarczającej wiedzy o grypie, epidemiologii i symptomatologii choroby oraz jej powikłaniach,

niewygód związanych ze szczepieniem, w tym konieczność poniesienia kosztów związanych $\mathrm{z}$ wykonaniem szczepienia,

błędnego przekonania o nieskuteczności szczepienia, błędnego przekonania o niskim ryzyku zakażenia,

lęku przed iniekcją.

Z kolei pracownicy medyczni wykonujący szczepienia przeciwko grypie najczęściej motywują to troską o własne zdrowie (chęć ochrony siebie) (33-93\%), a w drugiej kolejności - chęcią ochrony swoich pacjentów (2-98\%) (26-29).

Działania promujące wykonywanie szczepień ochronnych przeciwko grypie powinny być ukierunkowane na wzmacnianie czynników, które wpływają na wykonywanie szczepień, oraz na niwelowanie czynników zmniejszających chęć zaszczepienia się. Szczepienia przeciwko grypie dla personelu medycznego powinny być całkowicie bezpłatne (koszty zakupu, przechowywania i wykonania szczepienia ponosić powinien pracodawca). Przekonanie pracodawcy, że odsetek zaszczepionego przeciwko grypie personelu medycznego jest jednym ze wskaźników jakości opieki nad pacjentami stanowi często klucz do sukcesu w uzyskaniu funduszy na przeprowadzenie akcji szczepień personelu.
Ważne jest także umożliwienie wykonania szczepienia w miejscu i w godzinach pracy $(6,7,26-29)$.

W niektórych krajach szczepienie przeciwko grypie jest obowiązkowe, tzn. wymagane przez pracodawcę, co wynika m.in. z wymogów stawianych świadczeniodawcom usług medycznych przez ubezpieczycieli. Wśród organizacji i stowarzyszeń, które postulują obowiązkowe szczepienia personelu medycznego przeciwko grypie, znajdują się m.in. $(1,2)$ :

- Society for Healthcare Epidemiology of America (Amerykańskie Towarzystwo Epidemiologów Opieki Zdrowotnej),

American College of Physicians (Amerykańskie Kolegium Lekarzy),

American Academy of Pediatrics (Amerykańska Akademia Pediatrii)

American Academy of Family Physicians (Amerykańska Akademia Lekarzy Rodzinnych),

American Medical Directors Association (Amerykańskie Stowarzyszenie Menadżerów Medycznych), American Pharmacists Association (Amerykańskie Stowarzyszenie Aptekarzy),

American Public Health Association (Amerykańskie Stowarzyszenie Zdrowia Publicznego),

Association for Professionals in Infection Control and Epidemiology (Stowarzyszenie Profesjonalistów ds. Kontroli Zakażeń i Epidemiologii),

Infectious Diseases Society of America (Amerykańskie Towarzystwo Chorób Zakaźnych),

National Foundation for Infectious Diseases (Narodowa Fundacja na rzecz Chorób Zakaźnych),

National Patient Safety Foundation (Narodowa Fundacja Bezpieczeństwa Pacjenta).

W Europie poparcie dla postulatu obowiązkowych szczepień przeciwko grypie wśród personelu medycznego jest niskie (np. w badaniu holenderskim tylko $24 \%$ pracowników domów opieki wyraziło poparcie dla takiego rozwiązania) (30).

Warto zaznaczyć, że w Polsce wśród pytań zadawanych szpitalom przez podmioty ubezpieczające znajdują się także pytania o stan zaszczepienia personelu medycznego - nie tylko przeciwko wirusowemu zapaleniu wątroby typu B, ale także przeciwko grypie. Należy więc domniemywać, że pozostaje jedynie kwestią czasu, kiedy ubezpieczyciele będą uzależniać wysokość stawki ubezpieczeniowej dla podmiotów świadczących usługi medyczne zależne od parametru, jakim jest wyszczepialność przeciwko grypie personelu pracującego $\mathrm{w}$ danej placówce.

Zgodnie z zaleceniami ACIP dane o odsetku zaszczepionego personelu medycznego powinny być re- 
gularnie analizowane i przekazywane do wiadomości personelu oraz kierownictwa, $\mathrm{z}$ uwzględnieniem różnic zależnych m.in. od miejsca pracy (oddziału) danej osoby, posiadanej przez nią specjalizacji i pełnionej funkcji $(6,7)$. Poza tym odsetek zaszczepionego personelu powinien stanowić parametr oceny jakości opieki medycznej w placówkach, o którym należy regularnie informować odpowiednie instytucje i kadrę zarządzającą szpitala (26-29).

Coroczne szczepienia przeciwko grypie zalecają następujące towarzystwa naukowe i instytucje $(1,2)$ :

Advisory Committee on Immunization (Komitet Doradczy ds. Szczepień),

American Academy of Pediatrics (Amerykańska Akademia Pediatrii),

American Academy of Family Practice (Amerykańska Akademia Praktyk Lekarzy Rodzinnych),

- American Academy of Family Physicians (Amerykańska Akademia Lekarzy Rodzinnych),

- Working Party on Preventive Services (Partia Pracy na rzecz Usług Zapobiegawczych),

American College of Internal Medicine (Amerykańskie Kolegium Medycyny Wewnętrznej),

American Society of Internal Medicine (Amerykańskie Towarzystwo Chorób Wewnętrznych),

- American Society for Infectious Diseases (Amerykańskie Towarzystwo Chorób Zakaźnych),

- Canadian Working Group on Periodic Health Research (Kanadyjska Grupa Robocza ds. Okresowych Badań Zdrowotnych),

- American Cancer Society (Amerykańskie Towarzystwa Raka),

American College of Obstetrics and Gynecology (Amerykańskie Kolegium Położnictwa i Ginekologii),

- Executive Director of the Department of Health UK (Dyrektor Wykonawczy Wydziału Zdrowia Zjednoczonego Królewstwa Wielkiej Brytanii),

- American Heart Association / American College of Cardiology (Amerykańskie Stowarzyszenie Serca / / Amerykańskie Kolegium Kardiologii),

- Global Initiative on Chronic Obstructive Lung Disease (Światowa Inicjatywa na rzecz Przewlekłej Obturacyjnej Choroby Płuc),

- Global Strategy for Recognition, Treatment and Prevention of Asthma (Światowa Strategia Rozpoznawania, Leczenia i Zapobiegania Astmie).

Strategie promocji szczepień przeciwko grypie powinny obejmować $(6,7,26-29)$ :

- powtarzane co roku akcje edukacyjne na temat grypy i szczepionek informujące o:
- ryzyku zachorowania i powikłań wśród personelu oraz pacjentów,

- szczepionkach przeciwko grypie - ich skuteczności, bezpieczeństwie, różnicach między dostępnymi na rynku preparatami i innymi metodami profilaktyki,

- mitach i błędnych przekonaniach na temat szczepień przeciwko grypie,

ułatwienie wykonania szczepienia, czyli bezpłatne szczepienia w dogodnym dla pracowników miejscu i czasie z uwzględnieniem pracy na zmiany, stworzenie ruchomych punktów szczepień,

łatwo dostępne informacje o akcji szczepień w placówce,

zachęcanie do wykonania szczepienia:

- przykładowe szczepienie ordynatorów, dyrekcji i/lub innych lokalnych liderów opinii,

- wskazanie na potrzebę wykonania szczepienia przy zatrudnieniu na określonym stanowisku (np. oddziały przeszczepowe, oddziały pediatryczne),

- wskazanie na potrzebę złożenia pisemnej odmowy poddania się szczepieniu ( $\mathrm{z}$ wyjątkiem udokumentowanych przeciwwskazań medycznych).

Hood i wsp. opisali skuteczność programu edukacyjnego opartego na popularyzacji wiedzy o grypie i szczepieniach przeciwko grypie oraz na pozytywnym przykładzie liderów opinii, którzy poddawali się szczepieniom - w ciągu 2 lat trwania akcji edukacyjnej osiągnięto wzrost stanu zaszczepienia personelu z 66\% do 88\% (31). Abramson i wsp. wykazali w badaniu z randomizacją, że bardzo skuteczna była interwencja $\mathrm{w}$ formie wykładów dla personelu medycznego pracującego w praktykach ambulatoryjnych, po których pocztą mailową wysyłano broszury edukacyjne. Akcja spowodowała wzrost wyszczepialności do $52 \%$ w grupie edukowanej w porównaniu z 26\% w grupie kontrolnej (32).

W przypadku personelu medycznego pracującego w szpitalach skuteczne okazały się głównie interwencje, które polegały na zapewnieniu bezpłatnej szczepionki oraz zorganizowaniu punktów szczepień w miejscu pracy, działających w godzinach pracy personelu. Niestety, żadna badana interwencja, która miała na celu zwiększenie wyszczepialności przeciwko grypie do poziomu 90\%, nie przyniosła oczekiwanego rezultatu - z wyjątkiem szpitali, gdzie szczepienie było wymagane przez dyrekcję $(33,34)$.

Dowody naukowe na skuteczność poszczególnych interwencji mających na celu zwiększenie wyszczepialności przeciwko grypie pozwoliły na uszeregowanie poszczególnych zaleceń w tej kwestii w kilku kategoriach, co przedstawia tabela 6 . 
Tabela 6. Zalecenia dotyczące szczepień przeciwko grypie u personelu medycznego wraz z określeniem kategorii rekomendacji opartej na sile dowodów naukowych (35)

Table 6. The recommendations concerning influenza vaccinations of health care personnel and their categories based on evidence ranking system (35)

Edukacja pracowników medycznych w zakresie szczepień przeciwko grypie, potencjalnych korzyści z ich wykonywania dla personelu i pacjentów oraz w zakresie epidemiologii i transmisji zakażeń wywołanych wirusami grypy, diagnostyki, leczenia / Educational programs addressed to medical professionals, on influenza vaccination benefits to health care workers and patients, influenza epidemiology, transmission routes, influenza diagnosis and treatment

Coroczne oferowanie szczepionek przeciwko grypie pracownikom medycznym / Annual offering of influenza vaccines to medical professionals

Oferowanie pracownikom medycznym bezpłatnych szczepień możliwych do wykonania w miejscu pracy / Offering of influenza vaccines free to medical professionals and the opportunity to conduct vaccinations at workplaces

Wykorzystanie mobilnych punktów szczepień, umożliwienie wykonania szczepienia w czasie pracy (bez ograniczeń godzinowych), pozytywny przykład lokalnych liderów opinii / The use of mobile vaccination carts, vaccination available at special events, opportunity to conduct the vaccination during working hours (available on request), positive behaviors of local opinion leaders

Uzyskiwanie pisemnej odmowy wykonania szczepienia u pracowników bez przeciwwskazań medycznych do szczepienia / Obtaining from heath care workers a written refusal of influenza vaccination without medical contraindications for vaccination

Monitorowanie stanu zaszczepienia przeciwko grypie wśród personelu medycznego w czasie trwania akcji szczepień, zapewnienie informacji zwrotnej o wyszczepialności dla dyrekcji szpitala, ranking oddziałów i przedstawicieli poszczególnych specjalizacji medycznych (lekarskich i innych) wykonujących szczepienia przeciwko grypie najrzadziej i najczęściej / Monitoring of influenza vaccine coverage, providing a feedback for hospital management, ranking of wards and specializations with the best influenza vaccine coverage

Stosowanie poziomu wyszczepialności przeciwko grypie jako wskaźnika zapewniającego bezpieczeństwo i jakość usług dla pacjentów /

/ The use of influenza vaccine coverage as an indicator of a quality and safety of hospital services for patients

* Zasady interpretacji zaleceń według Komitetu Doradczego ds. Szczepień (ACIP) oraz Komitetu Doradczego ds. Zapobiegania i Kontroli Zakażeń Szpitalnych (HICPAC) (35): IA - postępowanie silnie zalecane do wprowadzenia i mocno poparte wynikami dobrze zaplanowanych badań eksperymentalnych, klinicznych lub epidemiologicznych; IB - postępowanie silnie zalecane do wprowadzenia i poparte wybranymi wynikami badań eksperymentalnych, klinicznych lub epidemiologicznych oraz mocnymi przesłankami teoretycznymi; IC - postępowanie wymagane do wprowadzenia na skutek istniejących regulacji administracyjnych; II - postępowanie sugerowane do wprowadzenia i poparte wynikami badań klinicznych lub epidemiologicznych lub przesłankami teoretycznymi / Rules of interpretation of recommendations according to the Advisory Committee on Immunization Practices (ACIP) and the Healthcare Infection Control Practices Advisory Committee (HICPAC) (35): IA - strongly recommended for implementation and strongly supported by well-designed experimental, clinical, or epidemiologic studies; IB - strongly recommended for implementation and supported by certain experimental, clinical, or epidemiologic studies and a strong theoretic rationale; IC - required for implementation, as mandated by federal or state regulation or standard; II - suggested for implementation and supported by suggestive clinical or epidemiological studies or a theoretic rationale.

\section{WNIOSKI}

Szczepienia przeciwko grypie powinny być traktowane jako element szczepień pracowniczych personelu medycznego, a także w kategoriach etycznych i moralnych. Powinno być rekomendowane wszystkim osobom pracującym w zakładach opieki medycznej - zarówno mającym bezpośredni kontakt $\mathrm{z}$ pacjentem, jak i pracownikom technicznym i administracyjnym.

\section{PIŚMIENNICTWO}

1. Brydak L.: Grypa. Pandemia grypy - mit czy realne zagrożenie? Rhythm, Warszawa 2008, ss. 1-92

2. Nitsch-Osuch A., Brydak L., Woźniak Kosek A.: Szybkie testy diagnostyczne w kierunku grypy - wady i zalety. Int. Rev. Allergol. Clin. Immunol. 2012;18(1):14-21
3. Centers for Disease Control and Prevention: Prevention and control of influenza with vaccines. Recommendations of the advisory committee on immunization practices (ACIP), 2011. MMWR Morb. Mortal. Wkly Rep. 2012;61(32):613-618

4. Weingarten B., Weingarten S., Riedinger M., Miles P., Ault M.: Barriers to influenza vaccine acceptance. A survey of physicians and nurses. Am. J. Infect. Control 1989;17(4):202-207

5. Foy H.M., Cooney M.K., Allan I.D., Albrecht J.K.: Influenza B in households: virus shedding without symptoms or antibody response. Am. J. Epidemiol. 1987;126(3): 506-515

6. Shefer A., Atkinson W., Friedman C., Kuhar D., Mootrey G., Bialek S.: Immunization of health-care personnel. Recommendations of the advisory committee on immu- 
nization practices. MMWR Morb. Mortal. Wkly Rep. 2011;60(RR-7):1-45

7. Rywczak I., Mrukowicz J.: Szczepienia dla personelu placówek opieki zdrowotnej - cz. 1. Zalecenia Amerykańskiego Komitetu Doradczego ds. Szczepień Ochronnych (ACIP) [cytowany 26 listopada 2012]. Adres: http://www.mp.pl/szczepienia/artykuly/wytyczne/show. html?id=71772

8. Carman W.F., Elder A.G., Wallace L.A., McAulay K., Walker A., Murray G.D. i wsp.: Effects of influenza vaccination of health-care workers on mortality of elderly people in long-term care: a randomized controlled trial. Lancet 2008;355(9198):93-97

9. Hayward A.C., Harling R., Wetten S., Johnson A.M., Munro S., Smedley J. i wsp.: Effectiveness of an influenza vaccine program for care home staff to prevent death, morbidity, and health service use among residents: cluster randomized controlled trial. Br. Med. J. 2006;333(7581): 1241-1248

10. Lemaitre M., Meret T., Rothan-Tondeur M., Belmin J., Lejonc J.L., Luquel L. i wsp.: Effect of influenza vaccination of nursing home staff on mortality of residents: A cluster-randomized trial. J. Am. Geriatr. Soc. 2009;57(9): 1580-1586

11. Nichol K.L., Mendelman P.M., Mallon K.P., Jackson L.A., Gorse G.J., Belshe R.B. i wsp.: Effectiveness of live, attenuated intranasal influenza virus vaccine in healthy, working adults: A randomized controlled trial. JAMA 1999;282(2):137-144

12. Wilde J.A., McMillan J.A., Serwint J., Butta J., O’Riordan M.A., Steinhoff M.C.: Effectiveness of influenza vaccine in health care professionals: a randomized trial. JAMA 1999;281(10):908-913

13. Salgado C.D., Farr B.M., Hall K.K., Hayden F.G.: Influenza in the acute hospital setting. Lancet Infect. Dis. 2002;2:145-155

14. Cunney R.J., Bialachowski A., Thornley D., Smaill F.M., Pennie R.A.: An outbreak of influenza $A$ in a neonatal intensive care unit. Infect. Control Hosp. Epidemiol. 2000;21(7):449-454

15. Weinstock D.M., Eagan J., Malak S.A., Rogers M., Wallace H., Kiehn T.E. i wsp.: Control of influenza A on a bone marrow transplant unit. Infect. Control Hosp. Epidemiol. 2000;21(11):730-732

16. Malavaud S., Malavaud B., Sandres K., Durand D., Marty N., Icart J. i wsp.: Nosocomial outbreak of influenza virus $A(\mathrm{H} 3 \mathrm{~N} 2)$ infection in a solid organ transplant department. Transplantation 2001;72:535-537

17. Maltezou H.C., Drancourt M.: Nosocomial influenza in children. J. Hosp. Infect. 2003;55:83-91
18. Kapila R., Lintz D.I., Tecson F.T., Ziskin L., Louria D.B.: A nosocomial outbreak of influenza A. Chest 1977;71: 576-579

19. Sartor C., Zandotti C., Romain F., Jacomo V., Simon S., Atlan-Gepner C. i wsp.: Disruption of services in an internal medicine unit due to a nosocomial influenza outbreak. Infect. Control Hosp. Epidemiol. 2002;23:615-619

20. Coles F.B., Balzano G.J., Morse D.L.: An outbreak of influenza A (H3N2) in a well immunized nursing home population. J. Am. Geriatr. Soc. 1989;40:589-592

21. Dorrell L., Hassan I., Marshall S., Chakraverty P., Ong E.: Clinical and serological responses to an inactivated influenza vaccine in adults with HIV infection, diabetes, obstructive airways disease, elderly adults and healthy volunteers. Int. J. STD AIDS 1997;8:776-779

22. Govaert T.M., Thijs C.T., Masurel N., Sprenger M.J., Dinant G.J., Knottnerus J.A.: The efficacy of influenza vaccination in elderly individuals. A randomized double-blind placebo-controlled trial. JAMA 1994;272:1661-1665

23. Stott D.J., Kerr G., Carman W.: Nosocomial transmission of influenza. Occup. Med. 2002;52:249-253

24. Christini A.B., Shutt K.A., Byers K.E.: Influenza vaccination rates and motivators among healthcare worker groups. Infect. Control Hosp. Epidemiol. 2007;28(2): 171-177

25. Fernandez W.G., Oyama L., Mitchell P., Edwards E.M., St. George J., Donovan J. i wsp.: Attitudes and practices regarding influenza vaccination among emergency department personnel. J. Emerg. Med. 2009;36(2): 201-206

26. Zielonka T.M., Lesiński J., Życińska K., Machowicz R., Królikowski K., Wardyn A.K.: Szczepienia przeciwko grypie personelu medycznego warszawskich szpitali klinicznych i studentów warszawskiego uniwersytetu medycznego. Med. Pr. 2009;60(5)369-376

27. Hofmann F., Ferracin C., Marsh G., Dumas R.: Influenza vaccination of healthcare workers: A literature review of attitudes and beliefs. Infection 2006;34(3):142-147

28. Schult T., Awosika E.R., Hodgson M.J., Hirsch P.R., Nichol K.L., Dyrenforth S.R. i wsp.: Innovative approaches for understanding seasonal influenza declaration in healthcare personnel support development of new campaign strategies. Infect. Control Hosp. Epidemiol. 2012;33(9):924-931

29. Burls A., Jordan R., Barton P., Olowokure B., Wake B., Albon E. i wsp.: Vaccinating healthcare workers against influenza to protect the vulnerable - is it a good use of healthcare resources? A systematic review of the evidence and an economic evaluation. Vaccine 2006;24(19): 4212-4221 
30. Looijmans-van den Akker I., Marsaoui B., Hak E., van Delden J.J.: Beliefs on mandatory influenza vaccination of health care workers in nursing homes: A questionnaire study from the Neth. J. Am. Geriatr. Soc. 2009;57(12): 2253-2256

31. Hood J., Smith A.: Developing a „best practice” influenza vaccination program for health care workers an evidence-based, leadership-modeled program. AAOHN J. 2009;57(8):308-312

32. Abramson Z.H., Avni A., Levi O., Miskin J.: Randomized trial of a program to increase staff influenza vaccination in primary care clinics. Ann. Fam. Med. 2010;8(4): 293-298
33. Cavalcante R.S., Jorge A.M., Fortaleza C.M.: Predictors of adherence to influenza vaccination for healthcare workers from a teaching hospital: A study in the prepandemic era. Rev. Soc. Bras Med. Trop. 2010;43(6):611-614

34. Rakita R.M., Hagar B.A., Crome P., Lammert J.K.: Mandatory influenza vaccination of healthcare workers: A 5-year study. Infect. Control Hosp. Epidemiol. 2010;31(9): 881-888

35. Centers for Disease Control and Prevention: Influenza vaccination of health-care personnel: recommendations of the Healthcare Infection Control Practices Advisory Committee (HICPAC) and the Advisory Committee on Immunization Practices (ACIP). MMWR 2006;55(No. RR-2)

Ten utwór jest dostępny w modelu open access na licencji Creative Commons Uznanie autorstwa - Użycie niekomercyjne 3.0 Polska / This work is available in Open Access model and licensed under a Creative Commons Attribution-NonCommercial 3.0 Poland License - http://creativecommons.org/ licenses/by-nc/3.0/pl. 